\title{
Thermochronology of central Ribeira Fold Belt, SE Brazil: Petrological and geochronological evidence for long-term high temperature maintenance during Western Gondwana amalgamation
}

\author{
Telmo M. Bento dos Santos ${ }^{\mathrm{a}, \mathrm{b}, *}$, José M. Munháb ${ }^{\mathrm{b}}$, Colombo C.G. Tassinari ${ }^{\mathrm{c}}$, \\ Paulo E. Fonseca ${ }^{\mathrm{b}}$, Coriolano Dias Neto ${ }^{\mathrm{c}}$ \\ ${ }^{a}$ LNEG - Laboratório Nacional de Energia e Geologia, 2720-866 Amadora, Portugal \\ b Centro de Geologia, Universidade de Lisboa, 1749-016 Lisboa, Portugal \\ c Instituto de Geociências, Universidade de São Paulo, 05508-080 São Paulo, Brazil
}

\section{A R T I C L E I N F O}

\section{Article history:}

Received 24 April 2009

Received in revised form 25 February 2010

Accepted 5 May 2010

\section{Keywords:}

Ribeira Fold Belt

Thermochronology

Cooling rate

Granulite

Western Gondwana

\begin{abstract}
A B S T R A C T
The studied sector of the central Ribeira Fold Belt (SE Brazil) comprises metatexites, diatexites, charnockites and blastomylonites. This study integrates petrological and thermochronological data in order to constrain the thermotectonic and geodynamic evolution of this Neoproterozoic-Ordovician mobile belt during Western Gondwana amalgamation.

New data indicate that after an earlier collision stage at $\sim 610 \mathrm{Ma}$ (zircon, U-Pb age), peak metamorphism and lower crust partial melting, coeval with the main regional high grade $\mathrm{D}_{1}$ thrust deformation, occurred at $572-562 \mathrm{Ma}$ (zircon, U-Pb ages). The overall average cooling rate was low $\left(<5^{\circ} \mathrm{C} / \mathrm{Ma}\right)$ from 750 to $250^{\circ} \mathrm{C}$ (at $\sim 455 \mathrm{Ma}$; biotite-WR Rb-Sr age), but disparate cooling paths indicate differential uplift between distinct lithotypes: (a) metatexites and blastomylonites show a overall stable $3-5{ }^{\circ} \mathrm{C} / \mathrm{Ma}$ cooling rate; (b) charnockites and associated rocks remained at $T>650^{\circ} \mathrm{C}$ during sub-horizontal $\mathrm{D}_{2}$ shearing until $\sim 510-470 \mathrm{Ma}$ (garnet-WR Sm-Nd ages) $\left(1-2{ }^{\circ} \mathrm{C} / \mathrm{Ma}\right)$, being then rapidly exhumed/cooled $\left(8-30^{\circ} \mathrm{C} / \mathrm{Ma}\right)$ during post-orogenic $\mathrm{D}_{3}$ deformation with late granite emplacement at $\sim 490 \mathrm{Ma}$ (zircon, $\mathrm{U}-\mathrm{Pb}$ age). Cooling rates based on garnet-biotite $\mathrm{Fe}-\mathrm{Mg}$ diffusion are broadly consistent with the geochronological cooling rates: (a) metatexites were cooled faster at high temperatures $\left(6^{\circ} \mathrm{C} / \mathrm{Ma}\right)$ and slowly at low temperatures $\left(0.1^{\circ} \mathrm{C} / \mathrm{Ma}\right)$, decreasing cooling rates with time; (b) charnockites show low cooling rates $\left(2{ }^{\circ} \mathrm{C} / \mathrm{Ma}\right)$ near metamorphic peak conditions and high cooling rates $\left(120^{\circ} \mathrm{C} / \mathrm{Ma}\right)$ at lower temperatures, increasing cooling rates during retrogression.

The charnockite thermal evolution and the extensive production of granitoid melts in the area imply that high geothermal gradients were sustained for a long period of time (50-90 Ma). This thermal anomaly most likely reflects upwelling of asthenospheric mantle and magma underplating coupled with long-term generation of high HPE (heat producing elements) granitoids. These factors must have sustained elevated crustal geotherms for $\sim 100 \mathrm{Ma}$, promoting widespread charnockite generation at middle to lower crustal levels.
\end{abstract}

(c) 2010 Elsevier B.V. All rights reserved.

\section{Introduction}

Experimental petrology and thermal modelling data have shown that different isotopic systems have different isotopic closure temperatures (e.g. Dodson, 1973; Mezger et al., 1992). Therefore, for the same rock, different isotopic systems will provide distinct geochronological results that can be used to obtain a

\footnotetext{
* Corresponding author at: LNEG - Laboratório Nacional de Energia e Geologia, 2720-866 Amadora, Portugal. Fax: +351 214719018

E-mail address: telmo.santos@lneg.pt (T.M. Bento dos Santos).
}

T-t evolution (thermochronology) and, ultimately, the cooling rates of that rock.

Several authors have tried to determine thermochronological evolutions and cooling rates, mainly based on low temperature fission track (e.g. Lim and Lee, 2005; Lee et al., 2006) and $\mathrm{Ar}-\mathrm{Ar}$ thermochronology (e.g. Glassmacher et al., 1999; Gray et al., 2006). However, the thermochronological data, cooling rates and the thermal evolution record of granulite belts from high temperatures $\left(\sim 800^{\circ} \mathrm{C}\right)$ to low temperatures $\left(\sim 250^{\circ} \mathrm{C}\right)$ is still very incomplete, worldwide. This has severely hampered the ability to constrain the processes involved in exhuming granulites from the middle/lower crust and the geodynamic evolution of the studied granulite belts themselves. 